\title{
Nietzsche and Virtue
}

\author{
Daniel I. Harris ${ }^{1}$
}

Published online: 19 June 2015

(C) Springer Science+Business Media Dordrecht 2015

"A confrontation with Nietzsche is a difficult thing to arrange." ${ }^{1}$ So writes Philippa Foot, whose own important confrontations with Nietzsche focused largely on his views concerning human virtue, goodness and flourishing. Nietzsche is a difficult philosopher to engage because, perhaps owing to the varied styles, tensions, and developments in his views, it can be difficult as readers to get a handle on just what Nietzsche is up to. Is he tearing down, or building up? Is he serious, or satirical? And if we say that he is all of these things, then we must ask how, in a principled way, we should draw lines between these and other strategies in a given work, or passage.

Nietzsche's views on virtue serve as an example of these challenges. In part seven of Beyond Good and Evil, "Our Virtues," Nietzsche begins not with an explanation or proclamation, but with a question:

Our virtues? - We probably still have our virtues too, although of course they will not be those trusting and muscular virtues for which we hold our grandfathers in honor - but also slightly at arm's length. We Europeans from the day after tomorrow, we firstborn of the twentieth century, - with all of our dangerous curiosity, our diversity and art of disguises, our worn-out and, as it were, saccharine cruelty in sense and in spirit, - if we happen to have virtues, they will presumably only be the ones that have learned best how to get along

\footnotetext{
1 Philippa Foot, Virtues and Vices and Other Essays in Moral Philosophy (Berkeley: University of California Press, 1978), p. 82.
}

Daniel I. Harris

danieliharris@outlook.com

1 Department of Philosophy, Hunter College of the City of New York, 695 Park Avenue, New York, NY 10065, USA 
with our most secret and heartfelt propensities, with our most fervent desires.

So let us look for them in our labyrinths! $(B G E 214)^{2}$

However qualified or tentative, Nietzsche's frequent engagement with the language of virtue invites a confrontation between Nietzsche and virtue ethics, and for reasons fundamental to Nietzsche's thought. For Nietzsche, throughout his career, was concerned to outline a vision of individual human excellence, its content and cultivation and its cultural preconditions and impediments. In both Nietzsche studies and contemporary virtue ethics, we find support for the claim that morality concerns not primarily what we do or do not do, or what follows from our actions, but instead asks what counts as flourishing for a human being, as a good human life overall.

The papers in this collection seek to address Nietzsche's views on virtue. And yet, as with Nietzsche himself in $B G E 214$, we begin not with answers but with questions. For even before one asks after convergences between Nietzsche and virtue ethics, one need ask whether Nietzsche has an ethics at all, or is instead, as he indeed sometimes calls himself, an immoralist, a critic not of this or that morality but of the very idea of morality. And if his thought does have a prescriptive element, we need to ask whether his talk of herds, slaves and masters, his criticisms of egalitarianism, compassion and selflessness can be fruitfully married to a recognizable form of virtue ethics. Not surprisingly, then, the papers here take a variety of approaches to Nietzsche and virtue, not just in the conclusions drawn, but in the type and tenor of questions asked and investigated.

Mark Migotti offers an interpretation of On the Genealogy of Morality according to which the third essay's structure tells us something important about its place in the Genealogy, and about the nature of Nietzsche's genealogical project more generally. Migotti is keen to show how Nietzsche mixes historical and evaluative strategies in order to make a point about the place of ascetic ideals in the processes through which we have become the kind of human beings we are, with the kind of values we profess. Still in the Genealogy, Lester Hunt discusses Nietzsche's distinction between master and slave moralities in GM I. Master and slave, as human types, instantiate particular and incommensurable hierarchies of virtues. To be one or the other is to be a person for whom different traits of character appear as moral, and so Nietzsche's genealogical questioning is ultimately about what sort of virtues we ought to have. Hunt suggests that Nietzsche, in insisting that we choose either master or slave, artificially delimits the field of candidates, and argues that out of the virtues embedded in relationships of trade and exchange can be constructed a morality that escapes the respective shortcomings of master and slave moralities.

Discussing Nietzsche's immoralism, Jessica Berry urges us to take Nietzsche seriously when he writes that with his genealogical investigations, "belief in morality, in all morality totters" (GM P:6). Nietzsche does not put forward a virtue

${ }^{2}$ Nietzsche's texts will be cited parenthetically in text. I use the following translations and abbreviations:

$\mathrm{A}=$ The Anti-Christ, trans. R. J. Hollingdale (Harmondsworth, England: Penguin Books, 1968)

$\mathrm{BGE}=$ Beyond Good and Evil, trans. J Norman (Cambridge: Cambridge University Press, 2002)

$\mathrm{GM}=$ On the Genealogy of Morality, trans. M. Clark and A.J. Swenson (Indianapolis: Hackett Publishing, 1998) 
ethics because he does not put forward an ethics at all. Berry surveys past attempts to read Nietzsche as a virtue ethicist and suggests that they inevitably rely on a strategy of selective reading, and when we seek to read Nietzsche in full we see that we do a disservice to the radical import of his thought by casting him in the mold of a traditional moralist.

Ruth Abbey explores Christine Swanton's seminal work on Nietzsche and virtue ethics. Abbey suggests that Swanton's analysis is usefully augmented by attention to Nietzsche's concern in the middle period works with self-love, egoism and vanity. In those works, Nietzsche makes interesting and subtle progress towards an appreciation of the place of healthy self-regard in the psychology of the moral person.

Scott Jenkins discusses Nietzsche's view of truthfulness, and argues that Nietzsche puts forward a kind of caring about the truth as his highest virtue insofar as such truthfulness is motivated by the values of life. So motivated, truthfulness figures integrally in the vision of human greatness Nietzsche means to present to his readers. Christine Daigle is also concerned to discuss Nietzsche's account of virtue in connection with his picture of human greatness. Daigle takes authenticity to be Nietzsche's cardinal virtue, and traces Nietzsche's concern with it through his middle, free spirit works, attempting to situate Nietzsche's views with respect to those of Aristotle.

Mark Alfano discusses Brian Leiter's influential interpretation of Nietzsche on human types. For Alfano, types are neither immutable nor fixed so that a person's type may change over the course of her lifetime. What is intrinsically good, Alfano has Nietzsche suggesting, is not this or that type but is instead the sort of selfcultivation that leads to a person's acting from that unified set of virtues which best exemplifies her type. Rebecca Bamford brings Nietzsche's conception of a free death to bear on contemporary debates in biomedical ethics over the moral permissibility of physician-assisted death. Nietzsche can contribute to such debates, Bamford suggests, by helping us to conceive of decisions about our death, in also being decisions about what sort of life we lead, as crucial to our wellbeing. Dying well can be an aspect of having lived well.

Finally, Bernard Reginster discusses Nietzsche's claim in The Antichrist that the virtue of proficiency is the highest virtue. Proficiency is intimately linked to the feeling of overcoming resistance, the feeling of power, at the core of Nietzsche's thought. What is good is success in practices taken to matter, the feeling of effective agency. Reginster discusses Nietzsche's conception of proficiency as it figures in an unlikely place, namely capitalism and its celebration of the entrepreneurial spirit.

Representing a variety of interpretive strategies, and looking closely at a wide range of Nietzsche's works, the papers in this issue are nevertheless united by a common concern to make clear whether and how our understanding of Nietzsche is improved by paying closer attention to his treatment of virtue. That the contributors have been able to connect so many different themes from Nietzsche's work with so many different themes from virtue ethics suggests that such an endeavor is well worth the effort, and indeed calls for more work in future. For Nietzsche's overlapping projects of interrogating inherited values and of envisioning forms of human life outside of the present moral economy of guilt and retribution both grow out of concerns central to virtue ethics. That is, Nietzsche is asking whether morality in its present state is good for human beings, where what counts as good 
has to do with the kind of creatures we are, and so what it takes for us to flourish. If we seek a better understanding of Nietzsche here, then, with the paradigm of virtue as a guide, we should seek further confrontations with his work, however difficult such confrontations might be to arrange. 